\title{
CHLORINE CONCENTRATION IN CHILDREN`S SWEAT TEST
}

\author{
Danielius Serapinas ${ }^{1,2}$, Mantas Sauspreskis ${ }^{1}$, Justinas Žiūraitis ${ }^{1}$, Diana Barkauskiené1, \\ Marius Žemaitis ${ }^{1}$, Raimundas Sakalauskas ${ }^{1}$ \\ ${ }^{I}$ Department of Pulmonology and Immunology, Medical Academy, Lithuanian University of Health \\ Sciences, ${ }^{2}$ Mykolas Romeris University
}

Key words: health, chlorine concentration, child.

\begin{abstract}
Summary
It is essential to confirm or exclude the diagnosis of cystic fibrosis in time and with accuracy in order to avoid inappropriate testing. The aims of this study was to determine features of $\mathrm{Cl}$ ions concentration in patients sweat test that were suspected having cystic fibrosis and to evaluate correlation between this concentration and $\mathrm{C}$ reactive protein levels in serum. Results showed, that 9 out of 48 patients $(18,75 \%)$ showed higher than normal $\mathrm{Cl}$ ions concentration values. 6 of them $(12,5 \%)$ had a borderline concentration, while $3(6,25 \%)$ were possitive according to $\mathrm{Cl}$ ions concentration test. Mean value of $\mathrm{Cl}$ ions concentration in males sweat was $25,37 \mathrm{mmol} / 1(\mathrm{p}<0,05 ; \mathrm{PI}=21,05-30,40)$ and there was no statistical significance compared to mean $\mathrm{Cl}$ ions concentration in females sweat which was $24,44 \mathrm{mmol} / \mathrm{l}(\mathrm{p}<0,05 ; \mathrm{PI}=19,96-28,91)$. All genetic tests' results were negative for CFTR gene mutations. CRP test was performed in 17 cases $(35,42 \%)$. No statisticaly significant correlation between concentration of $\mathrm{Cl}$ ions in sweat and serum $\mathrm{CRP}$ was found $(r=-0,16 ; p=0,531)$. No statisticaly significant difference between $\mathrm{Cl}$ ions concentrations in sweat test according to gender was found in examined group. In our study no mutations of CFTR gene were found. Statisticaly significant correlation between $\mathrm{Cl}$ ions concentration in sweat test and serum CRP level was not found.
\end{abstract}

\section{Introduction}

Cystic fibrosis is autosomal recessive genetic disorder affecting function of exocrine glands. Most often lower respiratory tract, pancreas and sweat glands are affected. As a result of this disorder, sodium and chlorine concentrations increase in patients sweat. Sweat test plays mayor role in diagnosing cystic fibrosis. It is essential to confirm or exclude the diagnosis of cystic fibrosis in time and with accuracy in order to avoid inappropriate testing [1]. Last year an article was published which revealed that some blood biomarkers can be usefull to estimate the activity of cystic fibrosis and to predict pulmonary exacerbations. It was shown that C-reactive protein test has the most potential in clinical usage when the diagnosis of cystic fibrosis is present $[2,3]$. Futhermore, it is now known that lung function impairment was independently associated with elevated plasma levels of CRP $[3,4]$. One of our aims was to determine whether increase in CRP could predict the onset of cystic fibrosis symptoms, when clinicians suspect cystic fibrosis.

Aims of this study was to determine features of $\mathrm{Cl}$ ions concentration in patients sweat test that were suspected having cystic fibrosis and to evaluate correlation between this concentration and $\mathrm{C}$ reactive protein levels in serum.

\section{Methods}

We investigated retrospectively case files of patients with performed sweat test in period of 2011-2012 in Hospital of Lithuanian University of Health Sciences Kauno Clinic's Paediatrics department. These patients were suspected having cystic fibrosis $(\mathrm{n}=48)$. Results of $\mathrm{Cl}$ ions concentration in sweat test, information about genetic testing of cystic fibrosis transmembrane conductance regulator (CFTR) gene's mutations and levels of $\mathrm{C}$ reactive protein (CRP) were used in our study. $\mathrm{Cl}$ ions concentration in sweat test is borderline if results are between $40-60 \mathrm{mmol} / 1$, positive if exceeds $60 \mathrm{mmol} / \mathrm{l}$ concentration in sweat. CRP is positive if exceeds $5 \mathrm{mg} / \mathrm{l}$. Data were processed using SPSS v15 statistical software. Statistical significance is $p<0,05$. Correlation between $\mathrm{CRP}$ and $\mathrm{Cl}$ ions concentration in sweat test was evaluated using Pearson's correlation coefficient.

\section{Results and discussion}

Our studied group was comprised of 48 patients, 30 of 


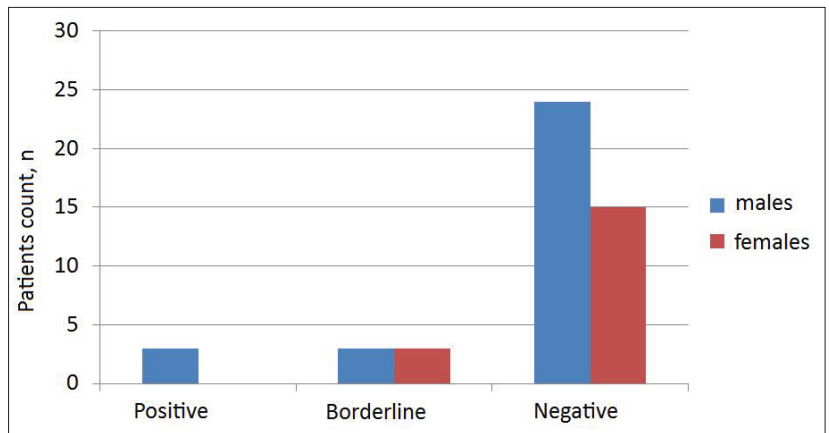

Figure 1. $\mathrm{Cl}$ ions concentration in sweat test

them were males, while 18 were females. Mean age when first symptoms occured was 3,8 $\pm 3,1$ years for males and $3,0 \pm 3,1$ years for females.First symptoms predominantly indicated respiratory tract lesions $-47(97,9 \%)$ patients. 1 patient had only gastrointestinal tract symptoms, $3 \mathrm{had}$ both respiratory tract and gastrointestinal tract symptoms. 9 out of 48 patients $(18,75 \%)$, who had been tested for sweat $\mathrm{Cl}$ ions concentration, showed higher than normal concentration values. 6 of them $(12,5 \%)$ had a borderline concentration, while $3(6,25 \%)$ were possitive according to $\mathrm{Cl}$ ions concentration test (Figure 1). 3 patients (50\%) who had a borderline increase were males and 3 patients (50\%) were females. All patients with possitive test results were males. Mean value of $\mathrm{Cl}$ ions concentration in males sweat was $25,37 \mathrm{mmol} / 1(\mathrm{p}<0,05 ; \mathrm{PI}=21,05-30,40)$ and there was no statistical significance compared to mean $\mathrm{Cl}$ ions concetrantion in females sweat which was $24,44 \mathrm{mmol} / 1$ $(\mathrm{p}<0,05$; $\mathrm{PI}=19,96-28,91)$. All patients who were possitive for $\mathrm{Cl}$ ions concentration in sweat test and one patient with borderline increase were tested geneticly for mutations of CFTR gene. All genetic tests' results were negative for CFTR gene mutations. CRP test was performed in 17 cases $(35,42 \%)$. The mean value was $32,31 \pm 73,68 \mathrm{mg} /$. 13 patients $(82,35 \%)$ had an increase in serum CRP. No statisticaly significant correlation between concentration of $\mathrm{Cl}$ ions in sweat and serum CRP was found $(\mathrm{r}=-0,16$; $\mathrm{p}=0,531$ ) (Figure 2). The reference ranges for normal sweat osmolality are $50-150 \mathrm{mmol} / \mathrm{kg}$, and values greater than $200 \mathrm{mmol} / \mathrm{kg}$ are consistent with CF [4- 8]. Borderline values are considered to be between $150-200 \mathrm{mmol} / \mathrm{kg}$ by some authors [9-10], others are considering values $<170$ $\mathrm{mmol} / \mathrm{kg}$ as normal [9]. Measuring osmolality can help as a screening method but it is not recommended for the diagnosis of CF [11-15]. Conductivity is the property of a solution that allows it to conduct a current. It depends on the concentration and mobility of the ions in the solution, and is therefore an indirect measurement of ions [16]. Sweat

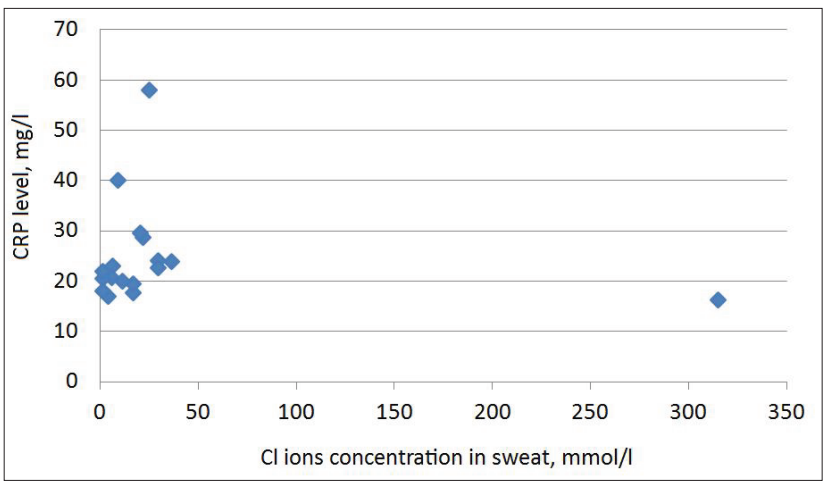

Figure 2. Pearson's correlation between $\mathrm{Cl}$ concentration in sweat and CRP in serum

conductivity is not equivalent to sweat chloride concentration because of other ions in sweat such as bicarbonate and lactate, therefore sweat conductivity is approximately 15 $\mathrm{mmol} / \mathrm{L}$ higher than the sweat chloride concentration [14]. According to the American CF Foundation, a conductivity value less than $50 \mathrm{mmol} / \mathrm{L}$ is considered normal and patients with values $>50 \mathrm{mmol} / \mathrm{L}$ should be referred for a quantitative pilocarpine iontophoresis test (QPIT) [17]. A conductivity level $>80 \mathrm{mmol} / \mathrm{L}$ is believed to be diagnostic in addition to its screening value by some authors [1825], while others suggest values $>90 \mathrm{mmol} / \mathrm{L}$ to support a diagnosis of CF [26]. The UK guidelines recommend that a sweat test can be performed after 2 weeks of age in infants $>3 \mathrm{~kg}$ [27], whereby others suppose that sweat collection can be reliably performed in infants $>36$ weeks postmenstrual age, $>2 \mathrm{~kg}$, and $>3$ days postnatal age [16]. Sweat testing should not be performed before a child is at least 48 hours old, as in the first 24 hours after birth, a baby's sweat electrolyte concentrations are known to rise transiently [28-30]. A sweat test should always be delayed in children who are dehydrated, systemically unwell or who have eczema affecting the potential stimulation sites, or who are oedematous and/or on systemic corticosteroids [14]. In addition, many other diseases can lead to false-positive and false-negative results which is described in detail elsewhere $[1,16]$.

\section{Conclusions}

$18,75 \%$ of checked patients had a higher than normal $\mathrm{Cl}$ ions concetration in sweat. No statisticaly significant difference between $\mathrm{Cl}$ ions concentrations in sweat according to gender was found in examined group. 33,33\% of patients who had $\mathrm{Cl}$ ions concentration in sweat above normal range were females and $66,66 \%$ were males. Genetic testing is performed usually only when the $\mathrm{Cl}$ ions concentration 
test in sweat is positive. In our study no mutation of CFTR gene were found and therefore no correlation between mutations of CFTR gene and chlorine concentration in sweat was found.

\section{Acknowledgements}

This article was possible with support from family clinic Alfa Clinic and Vilnius city municipality administration project for comunity health promotion.

\section{References}

1. Davis PB. Cystic fibrosis since 1938. Am J Resp Crit Care Med 2006;173:475-8.

2. Shoki AH, Mayer-Hamblett N, Wilcox PG. Systematic review of blood biomarkers in cystic fibrosis pulmonary exacerbations. Chest 2013;144:1659-70.

3. Mackay R, George P, Kirk J. Sweat testing for cystic fibrosis: A review of New Zealand laboratories. J Paediatr Child Health 2006;42:160-4.

4. Massie J, Clements B, Australian Paediatric Respiratory Group. Diagnosis of cystic fibrosis after newborn screening: the Australian experience - twenty years and five million babies later: a consensus statement from the Australian Paediatric Respiratory Group. Pediatr Pulmonol 2005;39:440-6.

5. Bush A, Wallis C. Time to think again: Cystic fibrosis is not an "all or none" disease. Pediatr Pulmonol. 2000;30:139-44.

6. De Boeck K, Wilschanski M, Castellani C, Taylor C, Cuppens $\mathrm{H}$, Dodge J, et al. Cystic fibrosis: terminology and diagnostic algorithms. Thorax 2006;61:627-35.

7. Knowles M, Durie P. What is cystic fibrosis? N Engl J Med 2002;347:439-42.

8. di Sant'Agnese PA, Darling RC, Perera GA, Shea E. Abnormal electrolyte composition of sweat in cystic fibrosis of the pancreas: clinical significance and relationship to the disease. Pediatrics 1953;12:549-63.

9. Gibson LE, Cooke RE. A test for concentration of electrolytes in sweat in cystic fibrosis of the pancreas utilizing pilocarpine by iontophoresis. Pediatrics 1959;23:545-9.

10. Carter EP, Barrett AD, Heeley AF, Kuzemko JA. Improved sweat test method for the diagnosis of cystic fibrosis. Arch Dis Child 1984;59:919-22.

11. LeGrys VA. Assessing quality assurance for sweat chloride testing. Clin Lab Sci. 1992;5:354-7.

12. Mastella G, Di Cesare G, Borruso A, Menin L, Zanolla L. Reliability of sweat-testing by the Macroduct collection method combined with conductivity analysis in comparison with the classic Gibson and Cooke technique. Acta Paediatr 2000;89: 933-7.

13. Barben J, Ammann RA, Metlagel A, Schöni MH. Conductivity determined by a new sweat analyzer compared with chloride concentrations for the diagnosis of cystic fibrosis. J Pediatr 2005; 146:183-8.
14. Hammond KB, Nelson L, Gibson LE. Clinical evaluation of the macroduct sweat collection system and conductivity analyzer in the diagnosis of cystic fibrosis. J Pediatr 1994;124:255-60.

15. Heeley ME, Woolf DA, Heeley AF. Indirect measurements of sweat electrolyte concentration in the laboratory diagnosis of cystic fibrosis. Arch Dis Child 2000;82:420-4.

16. Beauchamp M, Lands LC. Sweat-testing: A review of current technical requirements. Pediatr Pulmonol 2005;39:507-11.

17. Quinton PM. Physiological basis of cystic fibrosis: a historic perspective. Physiol Rev 1999; 79:S3-22.

18. Sheppard DN, Welsh MJ. Structure and function of the CFTR chloride channel. Physiol Rev 1999; 79:S23-45.

19. Kopelman H, Corey M, Gaskin K, Durie P, Weizman Z, Forstner G. Impaired chloride secretion, as well as bicarbonate secretion, underlies the fluid secretory defect in the cystic fibrosis pancreas. Gastroenterology 1988; 95:349-55.

20. Quinton PM, Reddy MM. CFTR, a rectifying, non-rectifying anion channel? J Korean Med Sci 2000; 15:S17-20.

21. Sohma Y, Gray MA, Imai Y, Argent BE. HCO3- transport in a mathematical model of the pancreatic ductal epithelium. J Membr Biol 2000; 176:77-100.

22. Reddy MM, Quinton PM. HCO3- impermeability via CFTR$\mathrm{Cl}$ conductance in sweat duct. Pediatr. Pulmonol Suppl 1993; 9:208.

23. Linsdell P, Tabcharani JA, Rommens JM, Hou YX, Chang XB, Tsui LC. et al. Permeability of wild-type and mutant cystic fibrosis transmembrane conductance regulator channels to polyatomic anions. J Gen Physiol 1997; 110:335-64.

24. Poulsen JH, Fischer H, Illek B, Machen TE. Bicarbonate conductance and $\mathrm{pH}$ regulatory capability of cystic fibrosis transmembrane conductance regulator. Proc Natl Acad Sci USA 1995; 91:5340-4.

25. Singh M, Krouse M, Moon S, Wine JJ. Most basal I(SC) in Calu3 human airway cells is bicarbonate-dependent $\mathrm{Cl}$ - secretion. Am J Physiol 1997; 272:L690-8.

26. Anderson MP, Sheppard DN, Berger HA, Welsh MJ. Chloride channels in the apical membrane of normal and cystic fibrosis airway and intestinal epithelia. Am J Physiol 1992; 263: L1-14.

27. Reddy MM, Quinton PM. Hydrolytic and nonhydrolytic interactions in the ATP regulation of CFTR Cl- conductance. Am J Physiol 1996; 271:C35-42.

28. Choi JY, Muallem D, Kiseyov K, Lee MG, Thomas PJ, Muallem S. Cystic fibrosis severity correlates with aberrant CFTR dependent HCO3- transport. Nature 2001; 410:94-7. [More details]

29. Reddy MM, Light MJ, Quinton PM. Activation of the epithelial $\mathrm{Na}+$ channel $(\mathrm{ENaC})$ requires CFTR Cl- channel function. Nature 1999, 402:301-04.

30. Quinton PM, Reddy MM. Control of CFTR chloride conductance by ATP levels through non-hydrolytic binding. Nature 1993; 360:79-81. 


\section{CHLORO KONCENTRACIJOS YPATUMAI VAIKU PRAKAITO TYRIME}

D. Serapinas, M. Sauspreskis, J. Žiūraitis, D. Barkauskienė, M. Žemaitis, R. Sakalauskas

Raktažodžiai: sveikata, chloro kiekis, vaikas.

Santrauka

Chloro kiekis dažnai būna padidejjęs esant cistinès fibrozès diagnozei, tačiau esant lètinėms kvėpavimo takų ligoms chloro kiekis prakaite gali būti labai įvairus. Tyrimo tikslas nustatyti chloro koncentracijos prakaite ypatumus įtariant cistinę fibrozę. Metodika. Atrinktos istorijos pacientų, kuriems 2011-2012 metais buvo darytas chloro koncentracijos tyrimas ịtariant cistinę fibrozę $(n=48)$. Iš ligos istorijų surinkta chloro koncentracijos prakaite tyrimo rezultatai, duomenys apie genetinius cistinès fibrozès transmembraninị laidumą reguliuojančio baltymo koduojančio geno (CFTR) mutacijų tyrimus, bei $\mathrm{C}$ reaktyvaus baltymo (CRB) reikšmès. Chloro koncentracijos prakaite mėginys laikomas abejotinu, jei gauti rezultatai yra $40-60 \mathrm{mmol} / 1$ intervale, ir teigiamu, jei $>60 \mathrm{mmol} / \mathrm{l}$. CRB laikomas padidèjusiu, jei jo kiekis serume viršija 5mg/l. Gauti duomenys apdoroti SPSS v15 paketu. Reikšmingumo lygmuo pasirinktas $\mathrm{p}<0,05$. Sąsajos tarp $\mathrm{CRB}$ ir $\mathrm{Cl}$ koncentracijos prakaite tikrintos Pearson'o koreliacijos koeficientu. Rezultatai. Iš 48 pacientų, kuriems buvo tirta chloro koncentracija prakaite, $9(18,75 \%)$ nustatytos normą viršijančios reikšmès.
$6(12,5 \%)$ iš jų nustatytas abejotinas padidejjimas, 3(6,25\%) teigiamas chloro koncentracijos méginys. 3(50\%) pacientai su abejotinu mèginiu yra vyriškosios lyties, 3 (50\%) - moteriškosios. Visi pacientai su teigiamu mèginiu yra vyriškosios lyties. Vidutinis chloro koncentracijos kiekis vyriškosios lyties tiriamųų prakaite 25,73mmol/1 ( $<<0,05 ; \mathrm{PI}=21,05-30,40)$ statistiškai reikšmingai nesiskyrè nuo moteriškosios lyties tiriamujuc $24,44 \mathrm{mmol} / 1$ $(\mathrm{p}<0,05 ; \mathrm{PI}=19,96-28,91)$. Visiems pacientams su teigiamu chloro koncentracijos prakaite méginiu bei vienam su abejotinu atlikti genetiniai CFTR geno mutacijų tyrimai. Visų tyrimų rezultatai neigiami. CRB tyrimas atliktas $17(35,42 \%)$ pacientų, vidutinè

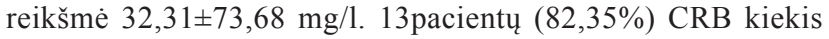
serume buvo padidèjęs. Statistiškai reikšmingos koreliacijos tarp chloro koncentracijos prakaite ir CRB serume nenustatyta $(r=-0,16$; $\mathrm{p}=0,531$ ). Gautos išvados parodè, kad genetinis tyrimas atliekamas tik nustačius teigiamą chloro koncentracijos prakaite mėginį, tačiau tyrimo metu mutacijų nustatyta nebuvo ir sąsajų tarp CFTR geno mutacijų ir chloro koncentracijos prakaite nenustatyta. Statistiškai reikšmingos koreliacijos tarp chloro koncentracijos prakaite ir CRB serume nenustatyta $(\mathrm{p}>0,05)$.

Adresas susirašinėti: dserapinas@gmail.com

Gauta 2015-01-26 